http://journal.uinsgd.ac.id/index.php/biodjati

\title{
DIVERSITY OF LAND AND FRESHWATER SNAIL (MOLLUSCA: GASTROPODA) OF LAIWANGI WANGGAMETI NATIONAL PARK, SUMBA ISLAND, INDONESIA
}

\author{
Nova Mujiono ${ }^{1 *}$, Nur Rohmatin Isnaningsih ${ }^{2}$
}

Received : August 05, 2021

Accepted : October 08, 2021

DOI: 10.15575/biodjati.v6i2.13521

${ }^{1,2}$ Research Center for Biology Indonesian Institute of Sciences (LIPI) Indonesia, Jl. Raua Jakarta-Bogor Km. 46 Cibinong, Bogor, 16911

e-mail:

*1nova.mzb@gmail.com

ish_naningsih@yahoo.com

*Corresponding author
Abstract. A study on the malacofauna of Laiwangi Wanggameti National Park (LWNP) in Sumba Island has been conducted. This study aims were to reveal the diversity of malacofauna in Sumba and compare it with those in the Lesser Sunda Islands. Observations were made on 20 stations using plots $(10 \times 10 \mathrm{~m})$ in Wanggameti and Laiwangi. Specimens were collected for two hours in each plot. Twenty families and 44 species have been identified. The overall number of species from Sumba increased from 126 to 143 species. The LWNP represents $31 \%$ diversity of malacofauna in Sumba Island. Seventeen species are considered as new records for the island. Five endemic land snail species are still observed inside the park. The diversity and population density tend to be higher in Laiwangi area with lower altitudes than in Wanggameti area with higher altitudes. Two dominant species are Asperitas bimaensis cochlostyloides and Tarebia granifera. Species composition in Sumba is more similar to Bali compared with the other six neighboring islands.

Keywords: diversity, endemic species, new record, Snail, Sumba Island.

\section{Citation}

Mujiono, N. \& Isnaningsih, N. R. (2021). Diversity of Land and Freshwater Snail (Mollusca: Gastropoda) of Laiwangi Wanggameti National Park, Sumba Island, Indonesia. Jurnal Biodjati, $6(2), 162-173$.

\section{INTRODUCTION}

Sumba Island lies in the Lesser Sunda Islands along with Bali, Lombok, Sumbawa, Flores, Timor, and many smaller islands. Administratively, Sumba consists of four districts namely West Sumba, Southwest Sumba, Central Sumba, and East Sumba that belong to the province of East Nusa Tenggara. The island extends around 10.854 $\mathrm{km}^{2}$. About $521 \mathrm{~km}^{2}(4.81 \%)$ are savannahs and grasslands, and $3.433 \mathrm{~km}^{2}(31.70 \%)$ are shrubs (Monk et al., 2000). The highest peak of the island is Mount Wanggameti (1225 $\mathrm{m}$ a.s.1.). The Laiwangi-Wanggameti forest complex in East Sumba is the largest and most important rainforest area in Sumba because they have a great contribution as the major water catchment area. To keep the function running, then the area needs to be conserved.

The floristic biodiversity in Laiwangi Wanggameti National Park (LWNP) has been long studied. The Park has 10 bamboo species (Widjaja \& Karsono, 2005), 70 fern species (Darma \& Peneng, 2007), and 33 moss species (Windadri \& Rosalina, 2020). Several faunistic studies also have been carried out in this area. At present, there are 40 dragonflies 


\section{JURNAL BIODJATI}

http://journal.uinsgd.ac.id/index.php/biodjati

including six endemic species (Onggo, 2015), 18 mammal species (Maharadatunkamsi \& Onggo, 2016), 17 reptiles including four endemic species, and five amphibian species (Tim Peneliti, 2015; Hamidy \& Dermawan, 2016), 21 bird including three endemic species (Royyani \& Onggo, 2016). The Sumba Cockatoo is endemic to Sumba and it has become the mascot of the park (Hidayat, 2012).

The study on molluscs inside the LWNP area has never been conducted. However, the history of molluscan studies on Sumba began in 1892. MM Schepman, a Dutch scientist, found 18 molluscs species including five new species (Schepman, 1892). EA Smith (1899) added one more species of land snail from Sumba. Shortly afterward, their studies were continued by Benthem Jutting in 1928 . She recorded 28 land snails, 14 freshwater snails, and two freshwater bivalve species. Bernhard Rensch (1931a, 1931b, 1932) and Benthem Jutting (1955 \& 1958) continued the study more comprehensively. Their result was then compiled by Monk et al., (2000) in the book entitled The Ecology of Nusa Tenggara and Maluku. In the last decade, studies on Sumbanese molluscs mostly focused on the land snail of the genus Amphidromus (Chan \& Tan, 2008 \& 2010; Cilia, 2013). Although there have been many studies on molluscs from Sumba Island, the opportunity for discovery is still widely open. This study aimed to reveal the diversity of malacofauna in Sumba and compare it with those in the Lesser Sunda Islands.

\section{MATERIALS AND METHODS}

\section{Site Location}

Field sampling was carried out in Laiwangi Wanggameti National Park, Sumba Island from 15 April to 4 May 2016. The altitude ranged between 402-1.113 m a.s.1. The study sites were divided into two areas, namely the Wanggameti area (site 1, station 1-11) and the Laiwangi area (site 2, station 12-20) (Figure 1). Site 1 was divided into 3 districts, namely Matawai Lapawu District (Wanggameti, MatawaiKalimbung, andKatiku Wai Village), Pinupahar District (Ramuk Village), and Lewa District (Watumbelar Village). Site 2 was in Tabundung District (Billa, Pinduhurani, Praing Kareha, and Wudi Pandak Village). Samples were taken from 20 stations (Table 1) where six stations for land habitat, ten stations for aquatic habitat, and four stations with both habitat types.

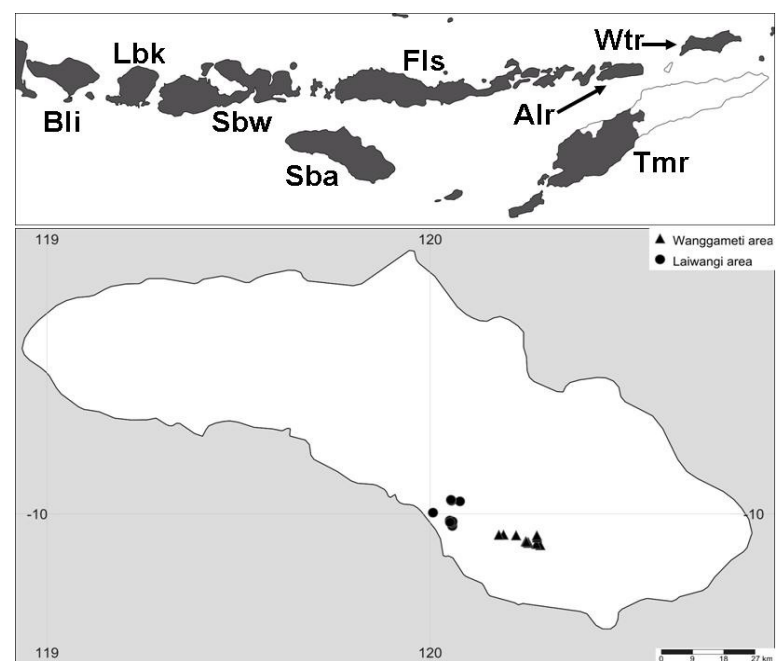

Figure 1. Sumba Island with two sites observed. Inset: Position of Sumba Island in the Lesser Sunda Islands of Indonesia. (Bli : Bali, Lbk : Lombok, Sbw : Sumbawa, Sba : Sumba, Fls : Flores, Tmr : Timor, Alr : Alor, Wtr : Wetar)

\section{Sampling Protocol}

This is exploratory research. The purposive sampling method was applied in this study. Snails were collected from plots $(10 \times 10 \mathrm{~m})$ in 20 stations (Monde et al., 2016; Nurinsiyah et al., 2016) and each plot was observed for two hours to ensure that no species was overlooked (Marzuki et al., 2021). Living snails and dead shells were preserved in $70 \%$ alcohol in plastic bottles (Marwoto 


\section{JURNAL BIODJATI}

http://journal.uinsgd.ac.id/index.php/biodjati

\& Shintosari, 1999). All specimens were brought, identified, and stored at the Museum Zoologicum Bogoriense (MZB). Previous studies (Schepman, 1892; Smith, 1899; Benthem Jutting, 1928, 1955, 1958; Rensch, 1931a, 1931b, 1932, 1934; Kohler, 2014; Kohler \& Kessner, 2014, 2020; Kohler et al., 2016, 2018, 2020) and museum collections were examined for identification. Species distributions around the Lesser Sunda Islands were compiled from references above and Vermeullen \& Whitten (1998) for Balinese land snails. If a species was not listed in the previous studies, they were considered as New Record. Species that only occurred in Sumba Island were considered endemic species.

\section{Data Analysis}

The frequency of species distribution was calculated by the number of stations where the species found was divided by the total number of observed stations. The categories were: constant species (ct : 100$76 \%$ ), common species (cn : 75-50\%), rare species (re : 50-25\%) and accidental species (al : $\leq 25 \%$ ) (Spyra, 2017; Rosales et al.,
2020). Shannon-Wiener's diversity index, Pielou's evenness index, and Simpson's dominance index were used in the analysis of snail communities (Magurran, 2004). Spearman rank correlation was used to measure the degree of association between altitude and species diversity or population (significant if $p<0.05$ ). Analysis of species composition was carried out using cluster analysis. Binary data (absent: 0, present: 1) were compiled from the occurrence of species between the station and between the island in the Lesser Sunda Islands (Schepman, 1892; Smith, 1899; Benthem Jutting, 1928, 1955, 1958, 1959; Rensch, 1931a, 1931b, 1934; Starmuhlner, 1974; Vermeullen \& Whitten, 1998). Jaccard similarity index was used in cluster analysis (Oke \& Chokor, 2011). The cophenetic correlation coefficient (r) was used to measure the pairwise distances between the original data. The categories were: very good fit $(\mathrm{r}>0.9)$, good fit $(0.8<\mathrm{r}<0.9)$, poor fit $(0.7<\mathrm{r}<0.8)$, and very poor fit $(\mathrm{r}<0.7)$ (Rohlf \& Fisher, 1968). All statistical analysis was performed using PAST 2.17c (Hammer et al., 2001).

Table 1. Localities and habitat types of sampling station

\begin{tabular}{lllll}
\hline Stations & \multicolumn{1}{c}{$\begin{array}{c}\text { Locality and Habitat } \\
\text { (F: freshwater, L: land) }\end{array}$} & Latitude & Longitude & $\begin{array}{c}\text { Altitude } \\
(\mathbf{m} . \mathbf{a . s . l .} .)\end{array}$ \\
\hline 1 & Lukularing River, Matawai Kalimbung Village (F) & -10.0578056 & 120.2242500 & 508 \\
2 & Laironja River, Wanggameti Village (F) & -10.0843167 & 120.2873417 & 932 \\
3 & Waimuru River, Wanggameti Village (F) & -10.0808889 & 120.2771611 & 962 \\
4 & Roadside of Wanggameti Forest, Wanggameti Village (L) & -10.0741889 & 120.2494194 & 1033 \\
5 & Laimuduk River, Katiku Wai Village (L, F) & -10.0561278 & 120.1913389 & 402 \\
6 & Ramuk River, Ramuk Village (F) & -10.0564417 & 120.1793389 & 447 \\
7 & Wanggameti Forest (hiking trails), Wanggameti Village (L) & -10.0764944 & 120.2560250 & 1083 \\
8 & Wanggameti Forest (ecology plot), Wanggameti Village (L) & -10.0781611 & 120.2557778 & 1113 \\
9 & Kanjilu River, Wanggameti Village (F) & -10.0636611 & 120.2789944 & 928 \\
10 & Front side of Kapumbung Cave, Wanggameti Village (L) & -10.0582000 & 120.2784083 & 993 \\
11 & Watumbelar riverside, Watumbelar Village (L) & -09.8052710 & 119.7652960 & 1043 \\
12 & Forest, Billa Village (L, F) & -09.9659528 & 120.0778167 & 277 \\
13 & Downstream of Pinduhurani River, Pinduhurani Village (L, F) & -09.9964167 & 120.0074722 & 34 \\
14 & Laputi Forest, Praing Kareha Village (L, F) & -10.0323500 & 120.0578750 & 482 \\
15 & Laputi Lake, Praing Kareha Village (F) & -10.0248750 & 120.0576694 & 488 \\
16 & Lameta River, Praing Kareha Village (F) & -10.0175556 & 120.0515611 & 330 \\
17 & Lamondu River, Praing Kareha Village (F) & -10.0202611 & 120.0583778 & 368 \\
18 & Limestone cave, Praing Kareha Village (L) & -10.0222889 & 120.0520139 & 412 \\
19 & Waturara River, Wudi Pandak Village (F) & -09.9641472 & 120.0555917 & 273 \\
20 & Katikataru River, Wudi Pandak Village (F) & -09.9618778 & 120.0544806 & 274 \\
\hline
\end{tabular}




\section{JURNAL BIDDJATI}

http://journal.uinsgd.ac.id/index.php/biodjati

\section{RESULTS AND DISCUSSION}

\section{Snail Communities}

Overall, 1.301 snail specimens were collected from two observed sites. It comprises 21 families and 44 species. Five families and nine species belong to freshwater snails, whereas 16 families and 35 species are land snails (Table 2). The number of specimens varied from nine to 239 individuals per station (average 65.05), while species richness varied from one to 28 (average 6.1). The molluscs community indices are presented in Table 3.
According to their location, 416 specimens representing 14 families and 26 species were observed from the Wanggameti area, and 885 specimens representing 16 families and 36 species were observed from the Laiwangi area. Only 15 species which observed in both sites. Snail populations are greatly varied in each station. In Wanggameti 11-91 individuals (average 38) were found, whereas 18-239 individuals were found from Laiwangi (average 98). That is two and a half times higher than in Wanggameti. (Figure 2. $a$ and $b$ )

Table 2. Composition and snail assemblages in Laiwangi Wanggameti National Park.

\begin{tabular}{|c|c|c|c|c|c|c|c|c|c|c|c|c|c|}
\hline Family & Species & Wa & La & $\mathbf{N}$ & D & $\mathbf{C}$ & Bli & Lbk & Sbw & Fls & Tmr & Alr & Wtr \\
\hline \multirow{3}{*}{ i. Achatinidae } & 1. Lissachatina fulica* & + & - & 31 & 1 & al & + & - & - & - & - & - & - \\
\hline & 2. Paropeas acutissimum & + & + & 3 & 2 & al & + & - & - & - & - & - & - \\
\hline & 3. Subulina octona * & - & + & 1 & 1 & al & + & - & - & - & - & - & - \\
\hline ii. Alycaeidae & 4. Chamalycaeus kessneri & - & + & 1 & 1 & al & + & - & - & - & - & - & - \\
\hline $\begin{array}{l}\text { iii. } \\
\text { Ampullariidae }\end{array}$ & 5. Pomacea canaliculata * & + & - & 1 & 1 & al & - & - & - & - & - & - & - \\
\hline \multirow{2}{*}{ iv. Ariophantidae } & 6. Macrochlamys robsoni & + & + & 7 & 2 & al & + & - & - & + & + & - & - \\
\hline & 7. Macrochlamys spiralifer & + & + & 16 & 5 & re & + & - & - & - & - & - & - \\
\hline v. Assimineidae & 8. Anaglyphula tiluana & - & + & 1 & 1 & al & - & - & - & - & - & - & - \\
\hline \multirow{4}{*}{ vi. Camaenidae } & 9. Amphidromus latestrigatus & - & + & 49 & 3 & al & + & - & - & - & - & - & - \\
\hline & 10. Landouria montana & + & + & 26 & 4 & al & + & + & + & + & + & - & - \\
\hline & 11. Landouria winteriana & - & + & 1 & 1 & al & + & - & - & + & + & - & - \\
\hline & 12. Parachloritis argillacea & + & + & 6 & 6 & re & - & - & - & + & + & + & - \\
\hline vii. Chronidae & 13. Vitrinopsis fruhstorferi & - & + & 1 & 1 & al & + & + & + & + & - & - & - \\
\hline \multirow{6}{*}{$\begin{array}{l}\text { viii. } \\
\text { Cyclophoridae }\end{array}$} & $\begin{array}{l}\text { 14. Cyclotus politus } \\
\text { sumbaensis" }\end{array}$ & - & + & 11 & 3 & al & - & - & - & - & - & - & - \\
\hline & 15. Cyclotus reticulatus & - & + & 8 & 3 & al & + & - & - & + & + & - & - \\
\hline & 16. Cyclotus sp & + & + & 14 & 4 & al & - & - & - & - & - & - & - \\
\hline & 17. Japonia ciliocincta & + & - & 2 & 2 & al & + & - & - & - & - & - & - \\
\hline & 18. Leptopoma helicoides & + & - & 11 & 3 & al & - & - & - & - & - & - & - \\
\hline & 19. Leptopoma perlucidum & + & + & 44 & 4 & al & + & - & + & + & + & + & - \\
\hline \multirow{5}{*}{$\begin{array}{l}\text { ix. } \\
\text { Diplommatinidae }\end{array}$} & 20. Arinia crassiventris “ & + & + & 19 & 2 & al & - & - & - & - & - & - & - \\
\hline & 21. Arinia tjendanae “" & + & - & 1 & 1 & al & - & - & - & - & - & - & - \\
\hline & 22. Diplommatina fluminis & + & + & 9 & 3 & al & + & - & - & - & + & - & - \\
\hline & 23. Palaina gedeana & + & - & 28 & 3 & al & + & - & - & - & - & - & - \\
\hline & 24. Palaina vulcanicola & - & + & 4 & 1 & al & + & - & - & - & - & - & - \\
\hline \multirow{4}{*}{ x. Dyakiidae } & $\begin{array}{l}\text { 25. Asperitas bimaensis } \\
\text { cochlostyloides “ }\end{array}$ & + & + & 103 & 7 & re & - & - & - & - & - & - & - \\
\hline & 26. Asperitas sp & - & + & 9 & 1 & al & - & - & - & - & - & - & - \\
\hline & 27. Asperitas sparsa & + & + & 10 & 2 & al & + & + & + & + & - & - & - \\
\hline & 28. Sasakina oxyconus & + & + & 21 & 4 & al & - & + & + & - & - & - & - \\
\hline
\end{tabular}




\section{JURNAL BIODJATI}

http://journal.uinsgd.ac.id/index.php/biodjati

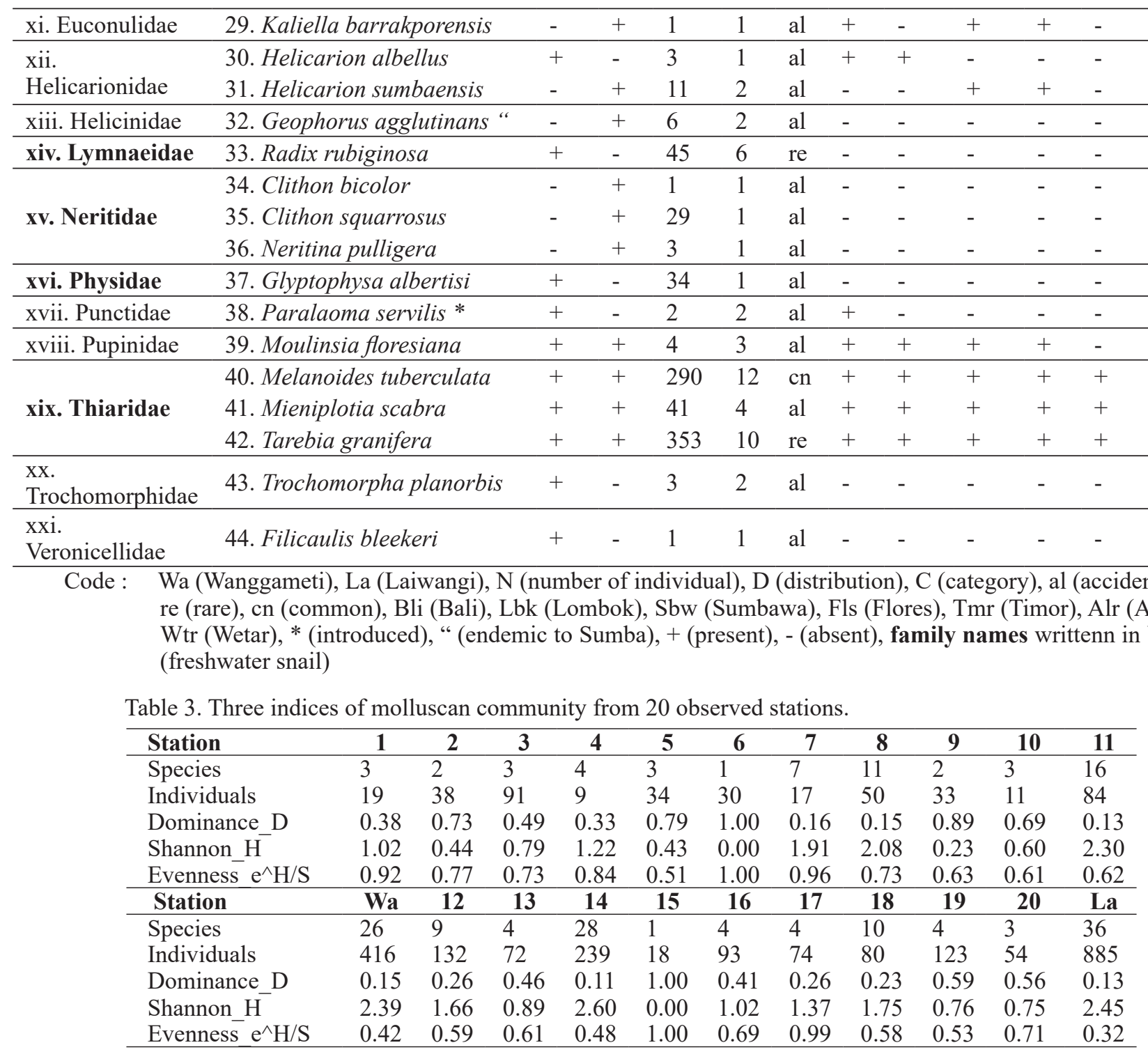

Code : Wa (Wanggameti), La (Laiwangi)
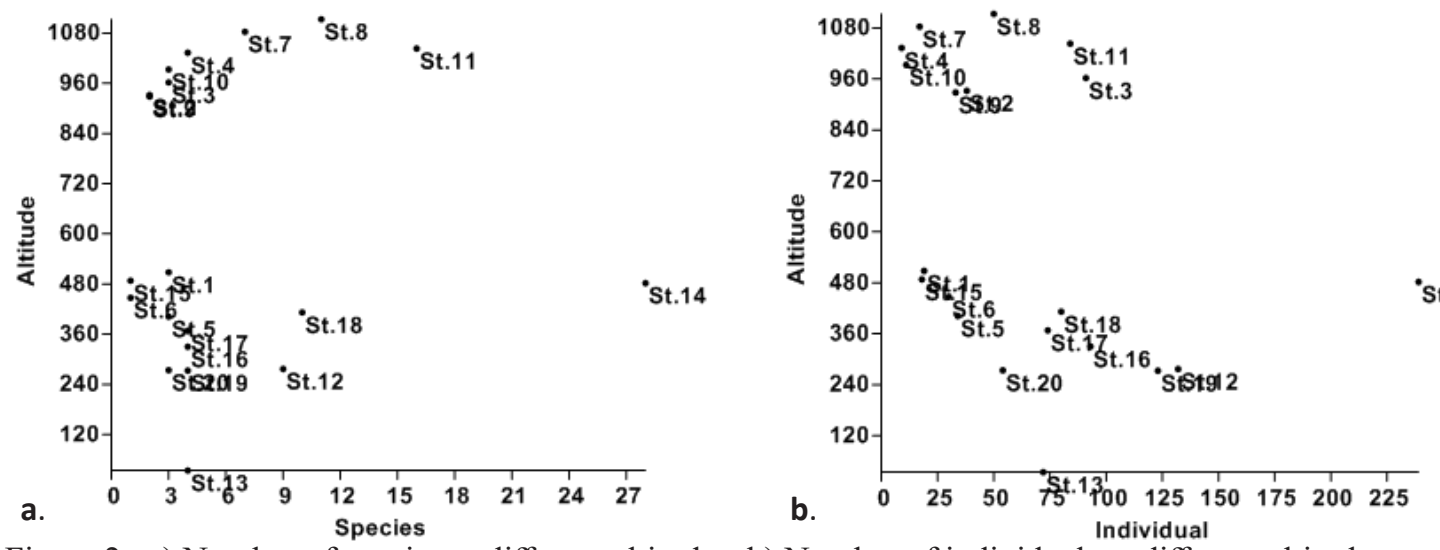

Figure 2. a) Number of species at different altitudes, b) Number of individuals at different altitudes 


\section{JURNAL BIODJATI}

http://journal.uinsgd.ac.id/index.php/biodjati

\section{Species Composition}

Based on the cluster analysis, two different groups of the station were formed (Figure 3. a). The first group consists of 12 stations with 10 snail species (nine freshwater and one land snail). There are eight stations in the second group, consist of 34 land snail species. This grouping is merely based on their habitat, i.e. freshwater and land snail, because almost all of the land snail species were formed the first group and all of the freshwater snail species were formed the second group (except Filicaulis bleeekeri which was observed attached to the stone in the riverside of Laimuduk River, station 5). However, three freshwater snails (Melanoides tuberculata, Tarebia granifera, Radix rubiginosa) were found in St.12 (Forest, Billa Village). Melanoides tuberculata was also observed in St.14 (Laputi Forest). The occurrences of freshwater snails in the forest were because there were two rivers flowing inside those forests. The plot was just located near the river bank.
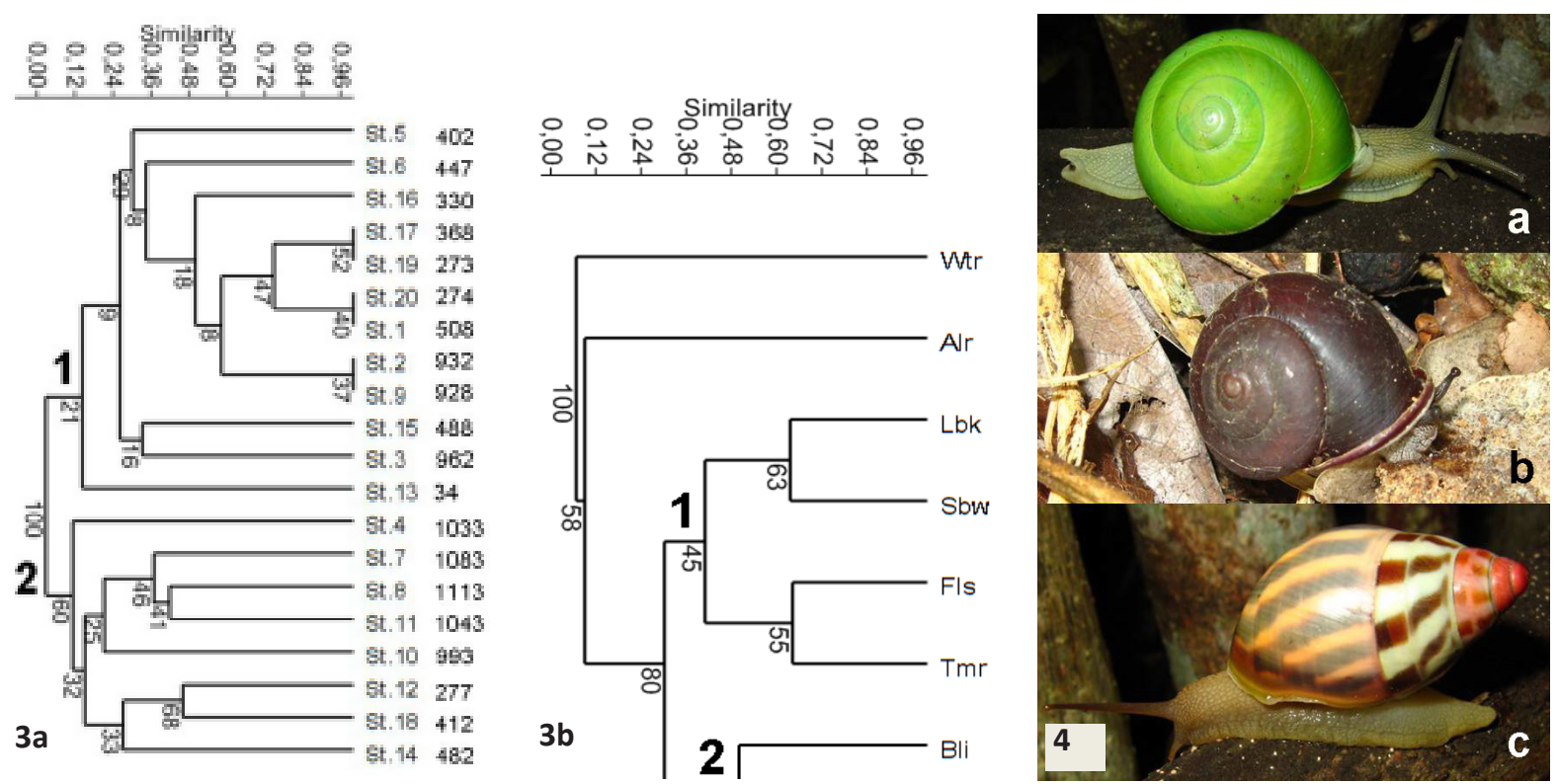

Figure 3. Dendrograms based on the similarity of species composition. a) Between stations, with altitude ( $\mathrm{r}$ : 0.93, very good), b) Between islands (r : 0.91, very good). (Sba : Sumba, Bli : Bali, Tmr : Timor, Fls : Flores, Sbw : Sumbawa, Lbk : Lombok, Alr : Alor, Wtr : Wetar).

Figure 4. Three land snails that frequently found and with striking shell color. a. A. bimaensis cochlostyloides, b. C. argillacea, c. A. latestrigatus

The most diverse and dense station in LNWP was St.14 with 28 species from 239 individuals snail, while the most diverse family found was Cyclophoridae with seven species. Asperitas bimaensis cochlostyloides was the dominant land snail species (103 individuals or $7.9 \%$ ), while $T$. granifera was the dominant freshwater snail (353 individuals or 27.1\%).
The molluscan community index varies greatly between stations. These indexes reflect the condition of the molluscs population in their habitat. The diversity index ranges from 0-2.6 with 10 stations each for the medium and low categories. The dominance index ranges from 0.11-1 with four stations each for high and medium categories and 12 stations with low 


\section{JURNAL BIODJATI}

http://journal.uinsgd.ac.id/index.php/biodjati

categories. Evenness index range from 0.48-1 with 15 stations in the high category and five stations in the medium category. Based on the value of the diversity index, it means that the ecosystem pressure occurs at a medium and high level. Domination is only observed from eight stations and most species are evenly distributed as observed from 15 stations (Magguran, 2004). Between all stations, station 14 can be considered to have the most stable ecological conditions for having the highest diversity index and lowest dominance index value.

\section{The Altitudinal Gradient on Diversity}

Snail populations were greatly varied in each station. Laiwangi area is more diverse and dense than the Wanggameti area even with fewer stations observed. Stations in Wanggameti were ranged from 402-1.113 m a.s.1. with an average of $858.5 \mathrm{~m}$ a.s.1., while stations in Laiwangi were ranged from 34$488 \mathrm{~m}$ a.s.1. with an average of $326.4 \mathrm{~m}$ a.s.1. Twelve stations were located between 34 to $508 \mathrm{~m}$ a.s.1. Nine hundred and sixty-eight individuals (range from 18-236) belonging to 37 species (range from 1-28) species were observed from this lower altitude. The other eight stations were located between 928 to $1,113 \mathrm{~m}$ a.s.1. Three hundred and thirty-three individuals (range from 9-91) belonging to 25 species (range from 2-16) were observed from this higher altitude (Figure 2. a, b). Spearman's rank correlation coefficient showed no significant correlation between altitude and number of species $(\mathrm{R}=0.5, \mathrm{p}=0.45)$ and between altitude and number of individuals $(\mathrm{R}=0, \mathrm{p}=1)$. Based on Spearman's value, no strong correlation between altitude and number of species nor individuals.

Previous studies on land snails from the sub-tropic region, Italy (Aubry et al., 2005) showed a strong correlation between altitude and the number of species or individuals. However, a similar study in the tropical region, Malaysian Borneo (Liew et al., 2010) did not show the same trend. Previous studies on aquatic snails only show decreasing in species richness with increasing altitude, whether in the sub-tropic region, Bulgaria (Georgiev \& Hubenov, 2013) or the tropical region, Brazil (Maltchik et al., 2010). Snail is a sessile animal with low dispersal abilities, each species has its preferred niche (Liew et al., 2010). On the other hand, niche type tends to be less diverse in the higher altitude (Aubry et al., 2005). Both reasons explain why higher altitude is less diverse than the lower one.

\section{Species Distribution}

As seen inFigure 2. a, b, both species distribution and population of snails are greatly varied. Seventeen species are only found from one station, even 10 of them only found as singleton. These are accidental species (al). Twenty-one species that occur between 2-4 stations are also accidental species (al). Five rare (re) species occur in 5-10 stations. Only $M$. tuberculata that occur in 12 stations are classified as common species (cn). The occurrence of species depends on their adaptation ability (Rosales et al., 2020). Only a small number of species can adapt to different habitats (here equal to the station and its altitude). They found that snails which are classified as common and constant species occur in the wide range of altitude (0700 m. a. s. 1.). Our data showed that $A$. $b$. cochlostyloides occur in seven stations (2771113 m. a. s. 1.) and M. tuberculata occur in 12 stations (34-962 m. a. s. 1.). While less diverse niche types are found in the higher altitude (Aubry et al., 2005), snails have to adapt to their surrounding environment.

Figure 3. a showed the species composition between 20 observed stations. 


\section{JURNAL BIODJATI}

http://journal.uinsgd.ac.id/index.php/biodjati

Group 1 mostly consists of stations below 900 m. a. s. 1., except for three stations (2, $3,9)$ that are located at a higher altitude. Only M. tuberculata occur in all 12 stations in group 1. Group 2 consists of species that occur above $900 \mathrm{~m}$. asl (A. b. cochlostyloides) and below $500 \mathrm{~m}$. asl (Amphidromus latestrigatus, Chloritis argillacea, Cyclotus politus sumbensis, C. reticulatus, Leptopoma vitreum, A. b. cochlostyloides).

There were 126 species known reported from Sumba (Schepman, 1892; Smith, 1899; Benthem Jutting, 1928, 1955, 1958, 1959; Rensch, 1931a, 1931b, 1934; Starmuhlner, 1974; Vermeullen \& Whitten, 1998). Species occurrence data in the Lesser Sunda Islands have been compiled from previous studies and museum collections. From 44 species observed in the present study, 24 species occur in Bali, 15 species occur in Flores, 11 species occur in Sumbawa, nine species occur in both Lombok and Timor, two species occur in Alor, and only one species occur in Wetar (Figure 3. b).

The similarity of species between Sumba and seven other islands is presented in Figure 3. b. Bali is grouped with Sumba based on 24 similar species. Timor and Flores share nine similar species, while eight species occur between Sumbawa and Lombok. Alor and Wetar can be considered as the out-group. The geological evidence reveals that Bali is part of the Asian plate and separated from the other islands in Lesser Sunda. In the other hand, Lombok, Sumbawa, Flores, Sumba, and Timor are part of the Wallacea region. During the Pleistocene, Bali, Java, and Sumatra were interconnected in one land together with the mainland of Asia and share the same Asian fauna (Satyana, 2012; Minarwan, 2012). The higher similarity in mollusc diversity between Sumba and Bali which is irrelevant with geology data, maybe due to the study of Vermeullen \& Whitten (1998) was more recent and comprehensive compared with the other studies. More species were identified from Bali, then the chance to find a similar species with Sumba is increase.

Five endemic land snail species were found in the present study. They only occur in Sumba Island and have never been reported from the neighboring islands. Cyclotus politus sumbaensis, Arinia crassiventris, and $A$. tjendanae were described based on specimens from Waingapu. Geophorus agglutinans was described from Langgaliru, while $A$. $b$. cochlostyloides was described from Katikuwai (Schepman, 1892; Rensch, 1932; Benthem Jutting, 1958).

Of 44 species found in this study, 17 of them have never been reported from Sumba and are considered as a new record for this island. Within the Lesser Sunda Islands, nine species were previously recorded from Bali (Pomacea canaliculata, Macrochlamys spiralifer, Chamalycaeus kessneri, Lagochilus ciliocinctum, Palaina gedeana, P. vulcanicola, P. caputspinulae, P. acutissimum, and Subulina octona). Helicarion albellus recorded from Bali and Lombok (Vermeullen \& Whitten, 1998; Suarmustika et al., 2018). Helicarion sumbaensis was recorded from Sumbawa and Flores (Rensch, 1932). Two species were never recorded from the Lesser Sunda Islands (Pupisoma tiluanum and Clithon bicolor) but they are present in Java (Benthem Jutting, $1952 \&$ 1956). The presence of C. bicolor in the Lesser Sunda Islands is already predicted because it also occurs in Moluccas (Benthem Jutting, 1959). Glyptophysa albertisi was previously recorded from Papua New Guinea (Starmuhlner, 1976). Lissachatina fulica and $P$. canaliculata are two introduced species that originated from Africa and South America. The previous record of Lissachatina fulica from Timor was in 1980 (Bruggen, 1981). 


\section{JURNAL BIDDJATI}

http://journal.uinsgd.ac.id/index.php/biodjati

The identities of two Cyclophorid species are questionable. Shell morphology of Cyclotus $\mathrm{sp}$. in this study is different from the four Cyclotus (C. pseudoreticulatus, C. succinctus, $C$. politus sumbaensis, $C$. reticulatus) previously known in Sumba. It also happens with Leptopoma. The shell is different from $L$. vitreum or L. moussoni that known to occur in Sumba, but is rather similar to L. bourguignat that known from Borneo. It is not surprising, because the other species, C. politus, also occur in both Borneo and Sumba (Rensch, 1932).

The result from the present study is still incomplete because it only documents 44 species of aquatic and land snail. However, 17 species of them have never been reported from Sumba. If the number accumulated with the previously known species from Sumba (126 species), then the overall number will be 143 species. The LWNP represents $31 \%$ diversity of malacofauna in Sumba Island. In the future, a more comprehensive study is needed to uncover the diversity of malacofauna from Sumba.

This present study is the first faunistic study of malacofauna in the Laiwangi Wanggameti National Park (LWNP). Twenty families and 44 species have been identified. Two dominant species are $A . b$. cochlostyloides and $T$. granifera, while $T$. granifera and $M$. tuberculata are two constant species that occur between 10-12 stations. The diversity and population density tend to be higher in Laiwangi area with lower altitudes than in Wanggameti area with higher altitudes. Species composition in Sumba is more similar to Bali compared with the other six neighboringislands. Seventeen species are considered as new records for Sumba and four species for the Lesser Sunda Islands. Five endemic species with a low population are still can be found inside the park.

\section{ACKNOWLEDGMENTS}

The author would like to thank all the members of the Widya Nusantara Expedition to Sumba, Andria Agusta and Oscar Effendi as the team principal and the field coordinator, and all the people in the Laiwangi Wanggameti National Park for their kindly help during the field trip. Alfiah and Riena Prihandini for their assistance during laboratory work, and the reviewers for their constructive advice to the manuscript.

\section{REFERENCES}

Aubry, S., Magnin, F., Bonnet, F. \& Preece, R. C. (2005). Multi-scale Altitudinal Patterns in Species Richness of Land Snail Communities in South-Eastern France. Journal of Biogeography, 32(6), 985-998.

Benthem Jutting, W. S. S. V. (1928). NonMarine Mollusca of Sumba. Treubia, 10(2-3), 153-162.

Benthem Jutting, W. S. S. V. (1952). Systematic Studies on the Non-Marine Mollusca of the Indo-Australian Archipelago. III Critical Revision of the Javanese Pulmonate Land-Snails of the Families Ellobiidae to Limacidae, with an Appendix on Helicarionidae. Treubia, 21(2), 291-435.

Benthem Jutting, W. S. S. V. (1955). Susswassermollusken von Sumba. Verhandlungen der Naturforschenden Gesellschaft in Basel, 66, 49-69.

Benthem Jutting, W. S. S. V.(1956). Systematic Studies on the Non-Marine Mollusca of the Indo-Australian Archipelago. V. Critical Revision of the Javanese Freshwater Gastropods. Treubia, 23(2), 259-477.

Benthem Jutting, W. S. S. V. (1958). Landmollusken von Sumba. 


\section{JURNAL BIDDJATI}

http://journal.uinsgd.ac.id/index.php/biodjati

Verhandlungen der Naturforschenden Gesellschaft in Basel, 69, 90-117.

Benthem Jutting, W. S. S. V. (1959). NonMarine Mollusca of the North Moluccan Islands Halmahera, Ternate, Batjan and Obi. Treubia, 25(1), 2-87.

Bruggen, A.C.V. (1981). Achatina fulica on The Island of Timor, Lesser Sunda Islands (Indonesia). Basteria, 45(4/5), 90.

Chan, S. Y. \& Tan, K. S. (2008). On a New Species of Amphidromus (Syndromus) (Gastropoda: Pulmonata: Camaenidae) from Sumba Island, Indonesia. Occasional Molluscan Papers, 1, 6-10.

Chan, S. Y. \& Tan, K. S. (2010). On Two New Species of Amphidromus (Gastropoda: Camaenidae) from the Lesser Sunda Islands, Indonesia. The Raffles Bulletin of Zoology, 58(2), 245-249.

Cilia, D. P. (2013). Description of a New Species of Amphidromus Albers, 1850 from Sumba, Indonesia (Gastropoda Pulmonata Camaenidae). Biodiversity Journal, 4(2), 263-268.

Darma, I. D. P. \& Peneng, I. N. (2007). Inventarisasi Tumbuhan Paku di Kawasan Taman Nasional LaiwangiWanggameti Sumba Timur, Waingapu, NTT. Biodiversitas, 8(3), 242-248.

Georgiev,D.\&Hubenov,Z.(2013).Freshwater Snails (Mollusca: Gastropoda) of Bulgaria: an Updated Annotated Checklist. Folia Malacologica, 21(4), 237-263.

Hamidy, A. \& Dermawan, B. (2016). Amfibi dan Reptil Sumba. Kakatua, 1, 27-32.

Hammer, Ø., Harper, D. A. T. \& Ryan, P. D. (2001). PAST: Paleontological Statistics Software Package for Education and Data Analysis. Palaeontologia Electronica, 4(1), 1-9.

Hidayat, O. (2012). Kakatua Sumba (Cacatua sulphurea cirinocristata) sebagai Satwa
Endemik Pulau Sumba. Warta Cendana, 7(1), 3-6.

Köhler, F. (2014). On the land snail Rhagada Albers, 1860 (Gastropoda: Camaenidae) from across the Lesser Sunda Islands. Raffles Bulletin of Zoology, 62, 115123.

Köhler, F. \& Kessner, V. (2014). Mitochondrial and Morphological Differentiation in a Previously Unrecognized Radiation of the Land Snail Genus Parachloritis Ehrmann, 1912 on Timor (Pulmonata: Camaenidae). Contributions to Zoology, 83(1), 1-40.

Köhler, F. \& Kessner, V. (2020). The Diplommatinidae of Timor-Leste, with Description of Five New Species (Gastropoda, Architaeniglossa, Cyclophoroidea). Molluscan Research, 40(3), 236-246.

Köhler, F., Criscione, F., Burghardt, I., \& Kessner, V. (2016). The Enidae of Timor (Stylommatophora: Orthurethra). Molluscan Research, 37(1), 8-16.

Köhler, F., Shea, M., Kessner, V. (2018). Two new species of Landouria GodwinAusten, 1918 from Timor-Leste (Stylommatophora, Camaenidae). Molluscan Research, 39(3), 253-264.

Köhler, F., Criscione, F., Hallan, A., Hyman, I. \& Kessner, V. (2020). Lessons from Timor: Shells Are Poor Taxonomic Indicators in Asperitas Land Snails (Stylommatophora, dyakiidae). Zoologica Scripta, 49(6), 732-745.

Liew, T. S., Schilthuizen, M. \& Lakim, M. (2010). The Determinants of Land Snail Diversity Along a Tropical Elevational Gradient: Insularity, Geometry and Niches. Journal of Biogeography, 37(6), 1071-1078.

Maharadatunkamsi \& Onggo, S. (2016). Mamalia di Taman Nasional Laiwangi Wanggameti. Kakatua, 1, 18-26. 


\section{JURNAL BIDDJATI}

http://journal.uinsgd.ac.id/index.php/biodjati

Magurran, A. E. (2004). Measuring Biological Diversity. Oxford: Blackwell Publishing.

Maltchik, L., Stenert, C., Kotzian, C. \& Pereira, D. (2010). Responses of Freshwater Molluscs to Environmental Factors in Southern Brazil Wetlands. Brazilian Journal of Biology, 7(3), 473482.

Marzuki, M. E, Liew, T. S. \& Mohd-Azlan, J. (2021) Land Snails and Slugs of Bau limestone Hills, Sarawak (Malaysia, Borneo), with the Descriptions of 13 New Species. ZooKeys, 1035, 1-113.

Marwoto, R. M. \& Shintosari, A. M. (1999). Pengelolaan Koleksi Moluska. Dalam Suhardjono, Y. R.(Ed). Buku Pegangan Pengelolaan Koleksi Spesimen Zoologi. Bogor: Puslitbang Biologi - LIPI.

Minarwan. (2012). Tectonic Models of the Lesser Sunda Islands. Berita Sedimentologi, 25, 8-15.

Monde, C., Syampungani, S. \& van den Brink, P. J. (2016). Natural and Human Induced Factors Influencing the Abundance of Schistosoma Host Snails in Zambia. Environmental Monitoring Assessment, 188, 370, 1-14.

Monk, K.A., Fretes, Y. D. \& Reksodihardjo, G. (2000). The Ecology of Nusa Tenggara and Maluku. Jakarta: Prenhallindo.

Nurinsiyah, A. S., Fauzia, H., Hennig, C. \& Hausdorf, B. (2016). Native and Introduced Land Snail Species As Ecological Indicators In Different Land Use Types in Java. Ecological Indicators, 70, 557-565.

Oke, O. C. \& Chokor, U. J. (2011). LandSnail Species Richness in a Rubber Plantation in Iyanomo, Edo State, Nigeria. Bioscience Research Journal, 23(1), 63-72.

Onggo, S. (2015). Ekspedisi Capung Sumba. Kakatua, 4, 13-26.
Rensch, B. (1931). Zur Kenntnis der Molluskenfauna Timors. Zoologische Jahrbücher Abteilung für Systematik, Ökologie und Geographie der Tiere, 60, 429-456.

Rensch, B. (1931). Die Molluskenfauna der Kleinen Sunda-Inseln Bali, Lombok, Sumbawa, Flores und Sumba. I. Zoologische Jahrbücher Abteilung für Systematik, Ökologie und Geographie der Tiere, 61, 361-396.

Rensch, B. (1932). Die Molluskenfauna der Kleinen Sunda-Inseln Bali, Lombok, Sumbawa, Flores und Sumba II. Zoologische Jahrbücher Abteilung für Systematik, Ökologie und Geographie der Tiere, 63, 1-130.

Rensch, B. (1934). Die Molluskenfauna der Kleinen Sunda-Inseln Bali, Lombok, Sumbawa, Flores und Sumba. III. Zoologische Jahrbücher Abteilung für Systematik, Ökologie und Geographie der Tiere, 65, 389-422.

Rohlf, F. J. \& Fisher, D. L. (1968). Test for Hierarchical Structure in Random Data Sets. Systematic Zoology, 17, 407-412.

Rosales, R., Lillo, E., Alcazar, S. M., Colita, L., Caballero, J. \& Malaki, A. B. (2020). Species composition, relative abundance, and distribution of land snail species in Mt. Lantoy Key Biodiversity Area, Cebu, Philippines. Biodiversitas, 21(11), 5438-5447.

Royyani, F. \& Onggo, S. (2016). Ekspedisi LIPI di PuLau Sumba: Menggali Harta Karun Biota. Kakatua, 1, 3-12.

Satyana, A. H.(2012). Bali-Lombok Gap: A Distinct Geo-Biologic Border of the Wallace's Line, Berita Sedimentologi, 25, 5-7.

Schepman, M. M. (1892). Land and Freshwater Shells Collected by Dr. H. Ten Kate in Soemba, Timor and Other East-Indian Islands. Notes from The 


\section{JURNAL BIDDJATI}

http://journal.uinsgd.ac.id/index.php/biodjati

\section{Leyden Museum, 14, 145-160.}

Smith, E. A. (1899). Diagnoses of New Land-Shell from the Islands of Flores, Sumbawa and Sumba. The Annals and Magazine of Natural History, 3(7), 409411.

Spyra, A. (2017). Acidic, neutral and alkaline forest ponds as a landscape element affecting the biodiversity of freshwater snails. The Science of Nature, 104(73), 1-12.

Starmuhlner, F. (1976). Beiträge zur Kenntnis der süßwasser-gastropoden Pazifischer Inseln. Ergebnisse der Osterreichischen Indopazifik-Expedition des Zoologischen Institutes der Universität Wien. Annalen des Naturhistorischen Museum in Wien, 80, 473-656.

Suarmustika, I. G. A., Suartini, N. M., \& Subagio, J. N. (2018). Variation
Morphometry and Morphological Character of Golden Apple Snail (Pomacea canaliculata) in rice field Abiansemal Village, Badung. Simbiosis, 6(2), 60-64.

Tim Peneliti (2015). Survei herpetofauna. Kakatua, 1, 9-15.

Widjaja, E. A. \& Karsono. (2005). Keanekaragaman Bambu di Pulau Sumba. Biodiversitas, 6(2), 95-99.

Windadri, F. I. \& Rosalina, D. (2020). Mosses from Laiwangi-Wanggameti National Park, Sumba, East Nusa Tenggara, Indonesia. Biodiversitas, 21(2), 538545.

Vermeullen, J, J. \& Whitten, A. J. (1998). Fauna Malesiana Guide to the Land Snail of Bali. Leiden: Backhuys Publishers. 